\title{
Vérzésmegelőzés és -kezelés a neuroanesztézia és neurointenzív ellátás során
}

\author{
Molnár Csilla dr. ${ }^{1}$ - Bereczki Dániel dr. ${ }^{2}$ - Fülesdi Béla dr. ${ }^{1}$ \\ ${ }^{1}$ Debreceni Egyetem, Általános Orvostudományi Kar, Aneszteziológiai és Intenzív Terápiás Klinika, Debrecen \\ ${ }^{2}$ Semmelweis Egyetem, Általános Orvostudományi Kar, Neurológiai Klinika, Budapest
}

\begin{abstract}
A központi idegrendszeren végzett mütéti beavatkozások és a spontán intracerebralis vérzések speciális kihívást jelentenek a vérzésmenedzsment során, hiszen egyrészt az agy az anaemiára és a következményes hypoxiára legérzékenyebb szervünk, másrészt a zárt koponyaüregben növekvő vérzés intracranialis nyomásfokozódás esetén közvetlen életveszélyt okoz. A szerző́k részletesen összefoglalják a neurointenzív ellátás és a neuroanesztézia során alkalmazott kezelési lehetőségeket. Elektív idegsebészeti mútétek esetén a perioperatív ellátásban kiemelt szerepet kap a hemoglobinkoncentráció, a fibrinogénszint és a thrombocytaszám szervspecifikus optimalizációja. Előzetesen szedett antikoaguláns és antithromboticus szerek esetén sürgősségi esetekben a célzott gyógyszeres korrekciót kell előnyben részesíteni. Intracerebralis vérzések esetén a szervtámogató kezelés mellett etiológiától függő, célzott diagnosztikán alapuló vérzéscsillapítás javasolt.
\end{abstract}

Orv Hetil. 2020; 161(37): 1574-1578.

Kulcsszavak: intracranialis mútétek, intracerebralis vérzés, célzott vérzéscsillapítás

\section{Management of bleeding in neuroanesthesia and neurointensive care}

Intracranial surgical interventions and spontaneous intracerebral hemorrhages challange neuroanesthesia and neurocritical care. First, the brain is the most sensitive organ to tissue hypoxia in the case of severe intraoperative bleedings and, second, a growing hemorrhage within the closed intracranial space may result in a ciritcal elevation of intracranial pressure resulting in an imminent life danger. The authors summerize the potential treatment strategies during neuroanesthesia and neurocritical care. Perioperative organ-specific optimalization of hemoglobin concentration, thrombocyte count and fibrinogen concentrations are key elements in elective neurosurgical interventions. Prior antithrombotic and anticoagulant treatment may indicate targeted pharmacological optimalization and treatment that should be based on laboratory diagnosis. In intracerebral hemorrhages, treatment strategy should be based on the etiology and laboratory diagnostics and targeted pharmacological treatment is preferable.

Keywords: intracranial surgery, intracerebral bleeding, targeted bleeding therapy

Molnár Cs, Bereczki D, Fülesdi B. [Management of bleeding in neuroanesthesia and neurointensive care]. Orv Hetil. 2020; 161(37): 1574-1578.

(Beérkezett: 2020. március 3.; elfogadva: 2020. május 20.)

\section{Rövidítések}

ARDS = (acute respiratory distress syndrome) akut légzési distressz szindróma; DOAC = direkt oralis antikoaguláns; ESO $=$ European Stroke Organisation; FFP = friss fagyasztott plaz$\mathrm{ma} ; \mathrm{Hb}=$ hemoglobin; OAC $=$ oralis antikoaguláns; $\mathrm{PCC}=$ protrombinkomplex-koncentrátum

\section{Perioperatív vérzésmenedzsment az idegsebészeti ellátásban}

Az emberi agy a testhez viszonyított kis tömege ellenére, magas anyagcseréje miatt a teljes test oxigénfogyasztásának 20-25\%-áért felelős. Az oxigénkínálatot az agyi vér- 
átáramlás és a vér oxigénszállító kapacitása határozza meg. Akutan kialakuló anaemia esetén cardiovascularis és cerebrovascularis kompenzációs mechanizmusok igyekeznek fenntartani a megfelelő oxigenizációt az agyban (percvolumen-emelkedés, cerebralis vasodilatatio, az oxigénextrakciós frakció emelkedése). Súlyos fokú anaemia esetén azonban már a kompenzációs mechanizmusok sem tudják ellensúlyozni az oxigénszállítás csökkenését, így ischaemia alakulhat ki [1].

Egészséges populációban történt felmérés igazolta, hogy 50-60 g/l-es hemoglobin ( $\mathrm{Hb}$ )-szint alatt már kognitív diszfunkció alakul ki [2]. Subarachnoidealis vérzés, craniotomia, intracerebralis vérzés esetén magasabb hemoglobinértékek mellett is bekövetkezhet ischaemia. Ugyanakkor az is ismert, hogy a transzfúziónak is súlyos, kimenetelt befolyásoló hatása lehet az idegsebészeti ellátás során (fokozott thromboemboliás rizikó, a vérzéses károsodás progressziója, halálozásnövekedés) [1, 3]. A fent említett folyamatokat figyelembe véve sem az optimális Hb-szint, sem a pontos transzfúziós határérték nem ismert az idegsebészeti ellátás során. Mind a restriktív, mind a liberális transzfúziós szemléletnek lehetnek előnyei, de általánosságban elmondható, hogy erről dönteni a betegségre és személyre szabottan kell.

\section{A mütét elötti anaemia kezelése}

A mütét előtt a fokozott vérzékenység felismerése és az anaemia kezelése az általános szempontok szerint kell, hogy történjen (1. táblázat).

Az idegsebészeti beavatkozások jelentős része (craniotomia, subarachnoidealis vérzés, aneurysmaklippelés, tumorreszekció, arteriovenosus malformatio mútéti ellátása, craniosynostosisműtét, gerincstabilizációs mütét) fokozott vérvesztéssel járhat. A transzfúziós igény csökkentésének része a mütét előtt a hemoglobinszint lehetőség szerint transzfúzió nélküli optimalizálása és a megfelelő thrombocytaszám biztosítása. Intracranialis vérzések esetében úgy találták, hogy a preoperatív anaemia jelenléte ( $\mathrm{Hb}$ férfiaknál: < $130 \mathrm{~g} / \mathrm{l}$, nóknél: <120 $\mathrm{g} / \mathrm{l})$ a hétszeresére növelte a rossz kimenetel előfordulá-

\section{1. táblázat |Vérzést csökkentő stratégiák a perioperatív szakban}

\begin{tabular}{|c|c|c|}
\hline Preoperatív & Intraoperatív & Posztoperatív \\
\hline $\begin{array}{l}\text { Coagulopathia } \\
\text { korrekciója } \\
\text { Anaemia korrekciója } \\
\text { Eritropoetin }\end{array}$ & $\begin{array}{l}\text { Coagulopathia } \\
\text { korrekciója } \\
\text { Hemoglobin } \\
\text { monitorozása } \\
\text { Cell saver } \\
\text { Antifibrinolitikus } \\
\text { terápia } \\
\text { NSAID kerülése } \\
\text { Hidroxi-etil-kemé- } \\
\text { nyítő mellőzése }\end{array}$ & $\begin{array}{l}\text { Coagulopathia } \\
\text { korrekciója } \\
\text { NSAID kerülése } \\
\text { Hidroxi-etil-kemé- } \\
\text { nyító mellózése }\end{array}$ \\
\hline
\end{tabular}

NSAID = nemszteroid gyulladáscsökkentő gyógyszer sát. Ez is arra utal, hogy elektív idegsebészeti beavatkozások előtt a vérkép optimalizálása elkerülhetetlen [4].

Idegsebészeti mútétek előtt indokolt a haemostasisvizsgálat elvégzése, a fibrinogénszint ellenőrzésével együtt. Az idegsebészeti beavatkozások elvégzéséhez az egyéb mútétekkel összehasonlítva magasabb minimális fibrinogénszint szükséges, itt ez a határ $2 \mathrm{~g} / 1$ [5].

A különböző irodalmi adatok ezen beavatkozások előtt még mindig szükségesnek tartják a thrombocytaszám 100 G/l minimális szintjét és annak fenntartását a posztoperatív 48-72 óra során, annak ismeretében is, hogy az abszolút thrombocytaszám nem szükségszerúen jelent megfelelő thrombocytafunkciót [6].

2. táblázat | Véralvadásgátló gyógyszerek hatásának antagonizálása sürgősségi helyzetben

\begin{tabular}{|c|c|}
\hline Véralvadásgátló & $\begin{array}{l}\text { A véralvadásgátlás felfüggesztésére javasolt } \\
\text { kezelés }\end{array}$ \\
\hline $\begin{array}{l}\text { K-vitamin-antagonista } \\
\text { Acenokumarol } \\
\text { Warfarin } \\
\text { INR }>1,5\end{array}$ & $\begin{array}{l}\text { PCC INR alapján, kezdő dózis } \\
25-50 \mathrm{U} / \mathrm{kg} \\
\text { K-vitamin } 5-10 \mathrm{mg} \\
\text { Ha PCC nem érhető el, FFP } 10-20 \mathrm{ml} / \\
\text { kg INR-tól függóen }\end{array}$ \\
\hline $\begin{array}{l}\text { Direkt Xa-gátlók } \\
\text { Apixaban } \\
\text { Edoxaban } \\
\text { Rivaroxaban }\end{array}$ & $\mathrm{PCC} 50 \mathrm{U} / \mathrm{kg}$ \\
\hline $\begin{array}{l}\text { Direkt trombingátlók } \\
\text { Dabigatrán } \\
\text { Argatrobán } \\
\text { Bivalirudin }\end{array}$ & $\begin{array}{l}\text { Dabigatrán esetén: idarucizumab } 5 \mathrm{~g} \text {, } \\
\text { vagy } \\
\text { további direkt trombingátló: } \\
\text { PCC } 50 \mathrm{U} / \mathrm{kg}\end{array}$ \\
\hline Nem frakcionált heparin & $1 \mathrm{mg}$ protamin-szulfát/100 U heparin \\
\hline $\begin{array}{l}L M W H \\
\text { Enoxaparin } \\
\text { Deltaparin } \\
\text { Nadroparin }\end{array}$ & $\begin{array}{l}\text { Enoxaparin adása }<12 \mathrm{~h} \\
\text { Protamin } 0,5-1 \mathrm{mg} / 1 \mathrm{mg} \text { enoxaparin } \\
\text { Deltaparin, nadroparin adása }<\text { fél életidő } \\
3-5 \times \\
\text { Protamin } 1 \mathrm{mg} / 100 \mathrm{U} \text { LMWH } \\
\text { Ha a protamin kontraindikált: } \\
\mathrm{rFVII} 90 \mu \mathrm{g} / \mathrm{kg}\end{array}$ \\
\hline $\begin{array}{l}\text { Indirect Xa-gátló } \\
\text { Fondaparinux }\end{array}$ & $\begin{array}{l}\text { Aktivált PCC } 20 \mathrm{U} / \mathrm{kg} \\
\text { vagy rFVII } 90 \mu \mathrm{g} / \mathrm{kg}\end{array}$ \\
\hline $\begin{array}{l}\text { Thrombocytaaggregáció- } \\
\text { gátlók: } \\
\text { ASA } \\
\text { Klopidogrél } \\
\text { Praszugrél } \\
\text { NSAID } \\
\text { CPIIb/IIIa inhibitor }\end{array}$ & $\begin{array}{l}\text { Dezmopresszin (DDAVP) } 0,4 \mu \mathrm{g} / \mathrm{kg} \text { iv. } \\
\text { Thrombocytaszuszpenzió }\end{array}$ \\
\hline $\begin{array}{l}\text { Thrombolyticus szerek } \\
\text { tPA }\end{array}$ & $\begin{array}{l}\text { Krioprecipitátum } 10 \mathrm{U} i \mathrm{v} \text {. } \\
\text { Tranexámsav } 10-15 \mathrm{mg} / \mathrm{kg} \\
\text { Aminokapronsav } 4-5 \mathrm{~g} i \mathrm{v} \text {. }\end{array}$ \\
\hline
\end{tabular}

ASA = acetilszalicilsav FFP = friss fagyasztott plazma; INR = nemzet közi normalizált ráta; $\mathrm{LMWH}=$ alacsony molekulasúlyú heparin; NSAID = nemszteroid gyulladáscsökkentő gyógyszer; $\mathrm{PCC}=$ protrombinkomplex-koncentrátum; rFVII faktor = a VII-es számú rekombináns véralvadási faktor; $\mathrm{tPA}=$ szöveti plazminogénaktivátor 


\section{Antikoaguláns és antithromboticus gyógyszerek basználata a mütét elött}

Az elektív mútéteknél a várható vérvesztés minimalizálásában jelentős szerepe van a korábban valamilyen okból szedett antikoaguláns és antithromboticus szerek megfelelő időben való leállításának, amennyiben szükséges, a megfelelő áthidaló kezelésnek. Ezeknek a mindenkori ajánlásoknak megfelelően kell történniük [7].

Sürgős esetben a haemostasis gyógyszeres korrekcióját kell előnyben részesíteni. A gyógyszeres korrekció legfontosabb előnye a haemostasis rövidebb időn belüli korrekciója, így minimalizálható az intracerebralis vagy subarachnoidealis vérzés növekedésének veszélye. Ezenfelül nem hanyagolható el az sem, hogy a transzfúziónak, a friss fagyasztott plazma és a thrombocyta adásának számos, a kimenetelt negatívan befolyásoló hatása (immunmoduláció-változás, folyadékterhelés, ARDS [akut légzési distressz szindróma], sebfertózés, cardialis szövődmények, hosszabb kórházi tartózkodás, magasabb halálozás) így csökkenthető.

A gyógyszeres korrekció lehetőségeit a 2. táblázat foglalja össze. Gyógyszeres korrekció lehetőségének hiányában a hagyományos módszereket kell alkalmazni az antikoaguláns és antithromboticus szerek hatásának felfüggesztésére [8].

\section{Intraoperatív szak}

Az intraoperatív allogén transzfúzió csökkentésére az idegsebészeti mútéteknél a preoperatív autológ véradás nem javasolható, mert ennek alkalmazásakor magasabb intraoperatív transzfúziós igényt állapítottak meg [9]. Elektív intracranialis mútétnél azonban hatékonynak találták a 'cell saver' használatát. A betegek 25\%-a kapott vissza legalább $500 \mathrm{ml}$ saját vért a mútét alatt, ezért ennek a technikának az alkalmazása támogatható [10]. A mútét során törekedni kell a véralvadás körülményeinek optimalizálására, megfelelő lélegeztetéssel, vércukorkontrollal, a szérumkalcium normalizálásával, a beteg aktív melegítésével, normothermiára törekvéssel.

Nagy várható vérvesztés esetén a vérzés minimalizálására előnyös lehet tranexámsav adása. Subarachnoidealis vérzés esetén már az aneurysmarupturát követően elindítható a telító, majd a fenntartó kezelés [11], de intracerebralis vérzés, tumorreszekció, gerincfixációs mútéteknél is csökkenthető a használatával az intraoperatív vérvesztés. Felnőttek esetében a tranexámsav telítő dózisa $10 \mathrm{mg} / \mathrm{kg}$, folyamatos adagolása elhúzódó mútét alatt megfontolható [12].

Gyermekek craniosynostosismútéténél a tranexámsav adagja sokkal magasabb lehet: $10-30 \mathrm{mg} / \mathrm{kg}$ telítő dózist követően $5-10 \mathrm{mg} / \mathrm{kg} / \mathrm{h}$ fenntartó adaggal kell számolni [13].

Az intraoperatív szakban folyadékterápiaként a krisztalloid oldatok adását kell előnyben részesíteni. A hidroxi-etil-keményítő-oldatok a thrombocytafunkciót befolyásolják, és ellentmondásos adatok jelentek meg az elmúlt években az intraoperatív vérzést befolyásoló hatásukról. Az utóbbi években azonban több tanulmány igazolta, hogy alkalmazásuk nem növeli az intraoperatív vérvesztés mértékét. Ezen adatok ismeretében az idegsebészeti anesztéziában csak körültekintéssel alkalmazhatók $[14,15]$.

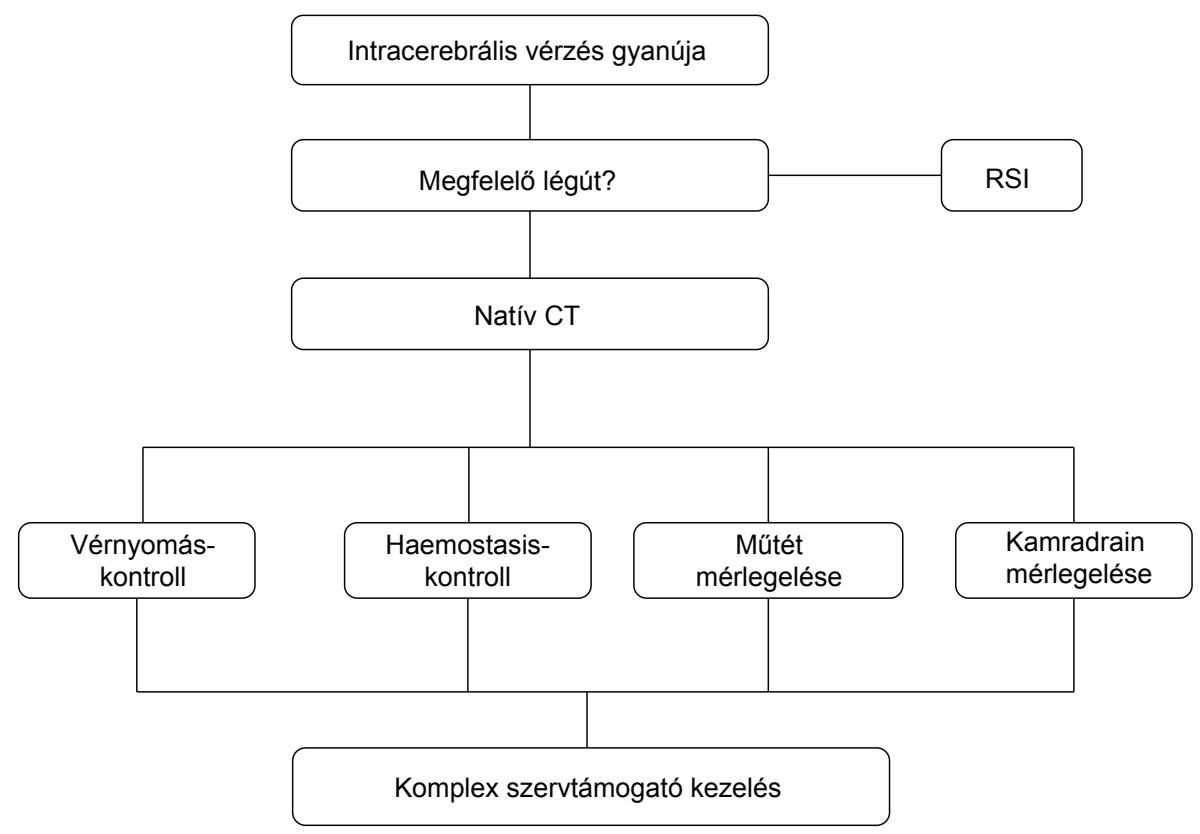

1. ábra $\quad$ Az akut idegsebészeti ellátás során a haemostasis kóros elváltozásainak korrekciója a vitális funkciók rendezésével, egyenrangú prioritással van az ellá tásba beágyazva

CT = komputertomográfia; RSI = gyors szekvenciaintubálás 
Masszív vérzés esetén a perioperatív vérzésmenedzsment elvei szerint kell eljárni, annak figyelembevételével, hogy az idegsebészeti mútétek alatt a fibrinogénszintet $2 \mathrm{~g} / \mathrm{dl}$ szint fölött kell tartani. Alacsonyabb értékek esetén megnő a vérzéses szövődmények előfordulása mind az intra-, mind a posztoperatív szakban [16].

\section{Intracerebralis vérzések személyre szabott kezelése}

$\mathrm{Az}$ intracerebralis vérzések az irodalmi adatok szerint a kaukázusi populációban az akut stroke-események 8-15\%-át teszik ki [17]. Létrejöttük kétharmadáért a krónikus hypertonia talaján kialakult kis arteriolaruptura mellett cerebralis amyloid angiopathiának, vascularis malformatióknak, sympathomimeticus szerekkel kapcsolatos abúzusnak (például kokain) és antithromboticus gyógyszerek alkalmazásának lehet szerepe. Ez utóbbi - elsősorban a K-vitamin-antagonisták szedését követő- en kialakuló, de az új típusú oralis antikoaguláns (OAC) szerek (dabigatrán, rivaroxaban, apixaban, edoxaban) szedéséhez társuló - spontán intracerebralis vérzések az esetek nagyjából 10-20\%-át adják, és az idősödő populáció és a cardialis kísérő betegségek gyógyszeres kezelése miatt az elmúlt évtizedben egyre gyakoribbá válnak. Az ajánlások [18-20] szerint az akut ellátás során a kezelés egyik alappillére a haemostasis abnormalitásainak tisztázása és megfelelő gyógyszeres kezelése. Ennek szempontjait az 1. ábrán foglaltuk össze.

A haemostasiseltérések diagnosztikájában mind a rutin-, mind az ágy melletti haemostasisvizsgálatoknak alapvető szerepük van. Az ajánlott algoritmus szerint spontán subarachnoidealis és traumás intracerebralis vérzés esetén első ellátásként a tranexámsav alkalmazása megfontolandó. Spontán intracerebralis vérzések esetén a teendőket az etiológia és a haemostasiseredmények határozzák meg. K-vitamin-antagonistával való túladagolás esetén az akut szakban elsődleges a protrombinkomplexkoncentrátum (PCC) adása. Az OAC hatásának felfüg-

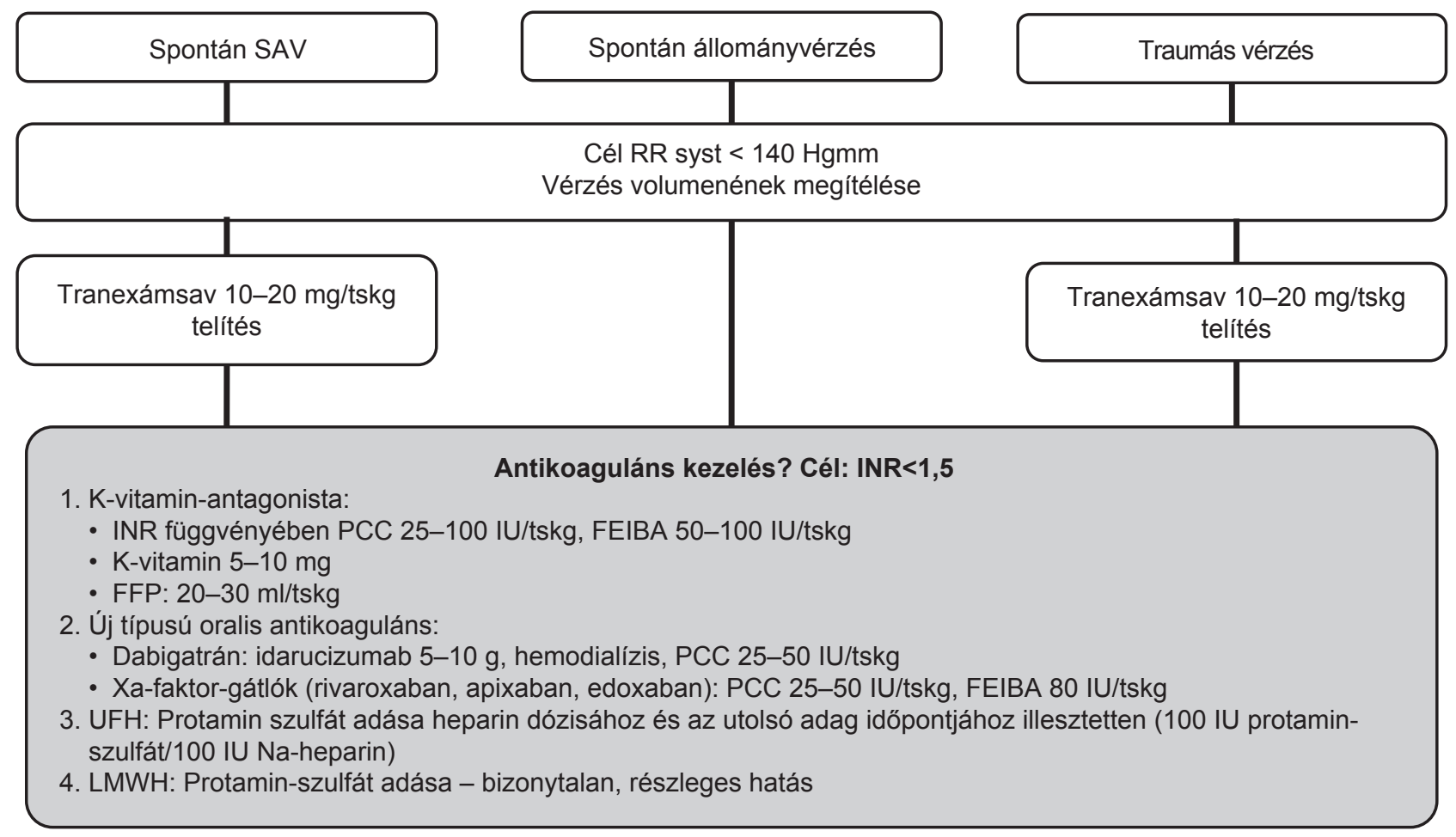

Fibrinogénhiány:

Fibrinogénkoncentrátum 2-4 g vagy FFP - cél: fibrinogén>2 g/l

\section{Thrombocytadeficit:}

Thrombocytafunkció javítása - dezmopresszin 0,3 $\mu \mathrm{g} / \mathrm{kg} 20-30$ perc alatt Thrombocytaszuszpenzió adása - $1 \mathrm{E} / 10 \mathrm{~kg}$

\footnotetext{
2. ábra $\quad$ Különböző haemostasisresuscitatiós stratégiák spontán intracerebralis vérzések esetén

FEIBA = factor eight inhibitor bypass actvity; FFP = friss fagyasztott plazma; INR = nemzetközi normalizált ráta; LMWH = alacsony molekulasúlyú heparin; $\mathrm{PCC}=$ protrombinkomplex-koncentrátum; $\mathrm{SAV}=$ subarachnoidealis vérzés; $\mathrm{UFH}=$ nem frakcionált heparin
} 
gesztésére a K-vitamin adása intracerebralis vérzésben nem megfelelő, hatása túlságosan lassan alakul ki. Ám akár faktorkészítményt, akár friss fagyasztott plazmát (FFP) adunk antidotumként, azt ki kell egészíteni K-vitamin adásával. Az OAC hatásának felfüggesztésére a faktorkészítményeket kell előnyben részesíteni, mert a beadandó FFP jelentős folyadékterhelést jelent, és az intracranialis nyomás (további) emelkedését okozhatja. A 2. ábrán azt foglaltuk össze, hogy az etiológia, a laboratóriumi leletek, valamint a klinikai kép alapján milyen vérzéscsökkentő stratégiákat alkalmazhatunk spontán intracerebralis vérzések esetén. A K-vitamin-antagonisták és a direkt oralis antikoagulánsok (DOAC-ok) mellett kialakuló agyvérzések ellátását az ESO 2019-es irányelve foglalja össze [21].

Anyagi támogatás: A közlemény megírása anyagi támogatásban nem részesült.

Szerzői munkamegosztás: Minden szerző részt vett az irodalomgyújtésben, a kézirat és az ábrák elkészítésében. A cikk végleges változatát valamennyi szerző elolvasta és jóváhagyta.

Érdekeltségek: A szerzők a kézirat elkészítésével kapcsolatban pénzügyi vagy egyéb személyes érdekeltséggel nem rendelkeznek.

\section{Irodalom}

[1] Kisilevsky A, Gelb AW, Bustillo M, et al. Anaemia and red blood cell transfusion in intracranial neurosurgery: a comprehensive review. Br J Anaesth. 2018; 120: 988-998.

[2] Weiskopf RB, Kramer JH, Viele M, et al. Acute severe isovolemic anemia impairs cognitive function and memory in humans. Anesthesiology 2000; 92: 1646-1652.

[3] Vedantam A, Yamal JM, Rubin ML, et al. Progressive hemorrhagic injury after severe traumatic brain injury: effect of hemoglobin transfusion thresholds. J Neurosurg. 2016; 125: 12291234.

[4] Kuramatsu JB, Gerner ST, Lücking H, et al. Anemia is an independent prognostic factor in intracerebral hemorrhage: an observational cohort study. Crit Care 2013; 17: R148.

[5] Zhou JJ, Chen, T, Nakaji P. Intraoperative blood and coagulation factor replacement during neurosurgery. Neurosurg Clin $\mathrm{N}$ Am. 2018; 29: 547-555.

[6] Beshay JE, Morgan H, Madden C, et al. Emergency reversal of anticoagulation and antiplatelet therapies in neurosurgical patients. Neurosurg. 2009; 112: 307-318.
[7] De Hert S, Staender S, Fritsch G, et al. Pre-operative evaluation of adults undergoing elective noncardiac surgery: updated guideline from the European Society of Anaesthesiology. Eur J Anaesthesiol. 2018; 35: 407-465.

[8] Frontera JA, Lewin JJ 3rd, Rabinstein AA, et al. Guideline for reversal of antithrombotics in intracranial hemorrhage: a statement for healthcare professionals from the Neurocritical Care Society and Society of Critical Care Medicine. Neurocrit Care 2016; 24: 6-46.

[9] McGirr A, Pavenski K, Sharma B, et al. Blood conservation in neurosurgery: erythropoietin and autologous donation. Can J Neurol Sci. 2014; 41: 583-589.

[10] Cataldi S, Bruder N, Dufour H, et al. Intraoperative autologous blood transfusion in intracranial surgery. Neurosurgery 1997; 40: 765-772.

[11] Anker-Møller T, Troldborg A, Sunde N, et al. Evidence for the use of tranexamic acid in subarachnoid and subdural hemorrhage: a systematic review. Semin Thromb Hemost. 2017; 43: $750-758$.

[12] Mebel D, Akagami R, Flexman AM. Use of tranexamic acid is associated with reduced blood product transfusion in complex skull base neurosurgical procedures: a retrospective cohort study. Anesth Analg. 2016; 122: 503-508.

[13] Goobie SM, Faraoni D. Tranexamic acid and perioperative bleeding in children: what do we still need to know? Curr Opin Anaesthesiol. 2019; 32: 343-352.

[14] Feix JA, Peery CA, Gan TJ, et al. Intra-operative hydroxyethyl starch is not associated with post-craniotomy hemorrhage. SpringerPlus 2015; 4: 350 .

[15] Li N, Statkevicius S, Asgeirsson B, et al. Effects of different colloid infusions on ROTEM and Multiplate during elective brain tumour neurosurgery. Perioperative Med. 2015; 4: 9.

[16] Wei N, Jia Y, Wang X, et al. Risk factors for postoperative fibrinogen deficiency after surgical removal of intracranial tumors. PLoS ONE 2015; 10: e0144551.

[17] Giroud M, Delpont B, Daubail B, et al. Temporal trends in sex differences with regard to stroke incidence: the Dijon Stroke Registry (1987-2012). Stroke 2017; 48: 846-849.

[18] Steiner T, Al-Shahi Salman R, Beer R, et al. European Stroke Organisation (ESO) guidelines for the management of spontaneous intracerebral hemorrhage. Int J Stroke 2014; 9: 840-855.

[19] Hemphill JC 3rd, Greenberg SM, Anderson CS, et al. Guidelines for the management of spontaneous intracerebral hemorrhage: a guideline for healthcare professionals from the American Heart Association/American Stroke Association. Stroke 2015; 46: 2032-2060.

[20] Claude Hemphill J 3rd, Lam A. Emergency neurological life support: intracerebral hemorrhage. Neurocrit Care 2017; 27(Suppl 1) 89-101.

[21] Christensen H, Cordonnier C, Körv J, et al. European Stroke Organisation Guideline on reversal of oral anticoagulants in acute intracerebral haemorrhage. Eur Stroke J. 2019; 4: 294306.

(Fülesdi Béla dr., Debrecen, Nagyerdei krt. 98., 4032 e-mail: fulesdi@med.unideb.hu)

A cikk a Creative Commons Attribution 4.0 International License (https://creativecommons.org/licenses/by/4.0/) feltételei szerint publikált Open Access közlemény, melynek szellemében a cikk bármilyen médiumban szabadon felhasználható, megosztható és újraközölhetö, feltéve, hogy az eredeti szerző és a közlés helye, illetve a CC License linkje és az esetlegesen végrehajtott módosítások feltüntetésre kerülnek. (SID_1) 